\title{
Determining the Impact of Intangible Assets on Intellectual Capital and Competitive Advantage in Banking
}

\author{
Ramla Sadiq* and Safia Nosheen ${ }^{* *}$
}

\begin{abstract}
This paper carries out the empirical tests in order to validate the hypothesis that resource intangibility, in the form of intangible assets, contributes towards the intellectual capital, and the competitive advantage in the banking sector. Furthermore, it also determines whether the intangibility of a banks' resources contribute towards the sustainability of the competitive advantage. Finally, it determines which aspects of the banking performance, the intangible assets actually contribute to. In this context, this research utilizes the secondary data, which is extracted from the annual reports of commercial banks that are listed on the primary stock exchanges of Pakistan. The sample that is taken into consideration is divided into two main categories in order to carry out the analysis. These categories include the classification into the Islamic banks and the conventional banks. The Islamic window operations have not been included in the analysis, as the details required for the variable calculations are not consistently available. Moreover, this bifurcation in the sample is also a unique aspect of this research, as the prior literature primarily focuses on the determinants of the intellectual capital in the banking sector. However though, there is no direct study regarding the differences in the resource intangibility in the Islamic banks and the conventional banks, and their subsequent impact on the intellectual capital and competitive advantage. The time frame for the analysis is taken from the year FY2008-FY2018. Also, the findings of this study lead to striking implications for both the Islamic banking theory and the managerial practices in the banking sector of Pakistan. The resource intangibility is to be managed very differently across both categories. Where the intangible assets represent a significant contribution to both the intellectual capital and the competitive advantage for Islamic banks, they also represent a negligible impact on the intellectual capital, and the competitive advantage for conventional banks. This holds true for the conventional performance measures that are taken for the banking sector as well, as shown in the robustness analysis. Future studies may
\end{abstract}

\footnotetext{
Assistant Professor, School of Business and Economics, University of Management and Technology, University of Management and Technology, Lahore, Pakistan.

** Assistant Professor, School of Business and Economics, University of Management and Technology, Lahore, Pakistan.
} 
focus on additional countries to determine the consistency of these patterns. Furthermore, the additional explorations are possible, especially when considering this phenomenon. These include the impact of the bank size, the market position, and the country of location, etc.

Keywords: Banking, CAMELS, competitiveness, intangible assets, intellectual capital, resource intangibility, Tobin's Q, VAIC.

\section{JEL Classification: G21, M41, O34.}

\section{Introduction}

A fundamental question in the corporate strategy and industrial organizations, pertains to how the strategic financial management decisions affect the firms' performance. While the existing literature extensively analyzes the non-financial firms' perspectives of strategic financial management, there is very little work that has been done on the resource intangibility, diversification, and risk impacts on the intellectual capital, and the competitive advantage. From a performance perspective, the development of intellectual capital, and its associated resources, can ensure sustainability in the business. Whereas, from a practical perspective, survival in any industry also requires maintaining a competitive advantage. When paired together, these two measures can be undertaken through a strategy of value addition and value creation. By analyzing the intangible assets, diversification, and risk results on the intellectual capital and competitive advantage, this framework can indeed be explored further.

There is a growing significance of the intangible assets, and their contribution to the firms' performance and productivity. This consequently affects the decision-making process as well. Moreover, this has proven to be especially true in developed economies, where the competition is based on the extent of innovation and progress. Interestingly, a considerable amount of efforts have been devoted to accurately identifying the intangible assets, and their subsequent functionality in the process development and productivity.

When we consider the intangible assets in research, this category includes all the immaterial resources which are an essential part of the value creation process, but cannot be accounted for in physical terms. This includes all the internal aspects of the process and design, from blueprints to equity, software to intellect, and human resource ability. The external 


\section{Competitive Advantage in Banking}

aspects of the process, and the design may include patents, copyrights, and licenses as well. Moreover, some extant research has gone a step further to incorporate the economic competencies that have been obtained through various consultancies.

It is imperative to mention here that all the empirical studies show that the intangible capital represents an essential and emergent component of the total assets. This validates the necessity of using intangibles as a determinant of productivity. Research shows that the investment in intangible assets is almost equivalent to the investment that is done in tangible assets in US firms (Corrado et al., 2006). This indicates that the developed economies consider intangible assets as equal contributors to value. Likewise, an analysis of research and development intensive firms in the US, shows that the value of the total assets increases by $57 \%$, when $R \& D$ expenditures and the organizational capital is considered in addition to the conventional financial accounts (Hulten \& Hao, 2008). For the Italian manufacturing firms, Bontempi and Mairesse (2008) calculated that the intangible capital amounts to one-third of the tangible stocks. This consistency not only indicates towards the significance of intangible assets in firm value, but also considers its increasing occurrence and the resulting value addition. It is, therefore, reasonable to argue that as markets develop, the intangible assets become a necessary element in maintaining a competitive advantage.

Diversification inevitably leads to the expansion into services and industries that are not a part of the core function of the banks. In the instance where the expansion is in a particular sector, with significantly high levels of competition, or where the bank lacks proficiency, the subsequent information asymmetry may result in risk-adjusted performance that is worse that before (Carlson, 2001; Mercieca, Schaeck, \& Wolfe, 2007).

(Albaity Mallek, \&Noman, 2019) determined the impact of competition on the stability in the banking institutions that are listed in the MENA region. For a time frame between the years2006 to 2015, these banking institutions have held a control in terms of the financial inclusion, productivity, and the macroeconomic instability. They also incorporated the bank-level controls, such as size, efficiency, diversification, and leverage. Thus, the findings show that those banks that tend to face lower levels of competition, ultimately have higher profitability, and are also exposed to lower levels of credit risk and insolvency risk. When considering this phenomenon across the Islamic banks and conventional 
banks, the effect is more pronounced in the preceding category (Albaity et al., 2019).

Another study attempting to understand the effects of revenue diversification, measured as the non-interest income, and asset diversification, on the profitability in Gulf Cooperation Council (GCC), for a time frame between 2003 to 2005, finds that the income diversification hurts the performance, while the asset diversification, in fact, leaves a positive impact on performance. It also shows that the investors do not perceive the high levels of asset diversification in a positive manner. This is intriguing, as it indicates that there is an optimal level of diversification that is acceptable to the investors. From the perspective of the Islamic banking system, as well as the conventional one, the asset diversification has a particularly strong, positive impact on the Islamic banks' performance (AlKhouri \& Arouri, 2019). This is important, as it indicates which category of a bank is better able to achieve a systematic advantage from the diversification.

Existing research on the intangible assets, most commonly focuses on the developed economies (specifically US-based firms, UK based firms, and the EU based firms). These studies also tend to be sector-specific, with most of the studies covering the information technology, pharmaceuticals, and the chemical sectors. Studies conducted on the intellectual capital, test its impact on the fundamental measures of performance. Once again, they consider this perspective from a fundamental performance perspective. Only one prior study was identified by the author that connected the intellectual capital and resource intangibility (El - Bannany, 2008). However, this research only analyzed the banks that have been listed in the UK. In terms of dividing the sample into Islamic banks and conventional banks, this is also a unique aspect of this research, as the prior literature primarily focuses on the determinants of the intellectual capital in the banking sector. However, there is no direct study regarding the differences in the intangibility of the resources that are utilized and demanded, in the Islamic banks and conventional banks, and their subsequent impact on the intellectual capital and the competitive advantage. Therefore, an essential gap that needs to be filled in the existing literature is that of addressing the impact of the intangible assets on the intellectual capital and competitive advantage.

This paper contributes towards both the literature and the policy in three ways. Firstly, it will be the first paper to address the prevalence of intangible assets in the banking sector, that too across a set of developing 
economies. Moreover, it will also be the first study to break down and analyzethe impact of the intangible assets on the intellectual capital, and the competitive advantage in this sample. Other than that, this paper contributes to the empiricalpolicy in two ways. Firstly, it will show the prevalence of intangible assets, and diversification across the banking sectors, and their subsequent impact on the intellectual capital, andthe competitive advantage that will follow. Following this, thepolicymakers can address which components of the intangible assets, and the intellectual capital require an additional amount of investment, in order to increase the performance. Secondly, this research will also show if, and to what extent, the intellectual capital and the competitive advantage will affect the risk profiles for the banks.

This paper empirically tests the hypothesis that resource intangibility, in the form of intangible assets, contributes towards achieving a competitive advantage in the banking sector. Furthermore, it also determines whether the intangibility of a banks' resources contributes to the sustainability of the competitive advantage. Finally, it determines whether the intangible assets contribute towards the bank's performance.

The objective of this study is to determine the impact of the resource intangibility on the intellectual capital and the competitive advantage in the banking sector. Furthermore, it also attempts to determine if the impact differs significantly across the conventional banks and the Islamic banks.

\subsection{Research Questions}

To achieve this objective, this study postulates the following research questions:

a) Does the resource intangibility affect the intellectual capital and the competitive advantage?

b) Does the effect of the resource intangibility on the intellectual capital differ significantly across the conventional and Islamic banks?

To test the targeted objective in light of the above literature review, this study proposes the following hypotheses in order to understand the implications of the resource intangibility on the intellectual capital and the competitive advantage:

H1a: The resource intangibility has a significant impact on the intellectual capital, and hence, a competitive advantage. 
H1b: The effect of the resource intangibility on the intellectual capital and the competitive advantage differs significantly across the conventional and the Islamic banks.

\subsection{Conceptual Framework}

Figure 1 outlines the research objective, in terms of the variables that are taken into account.

Figure 1: Conceptual Framework

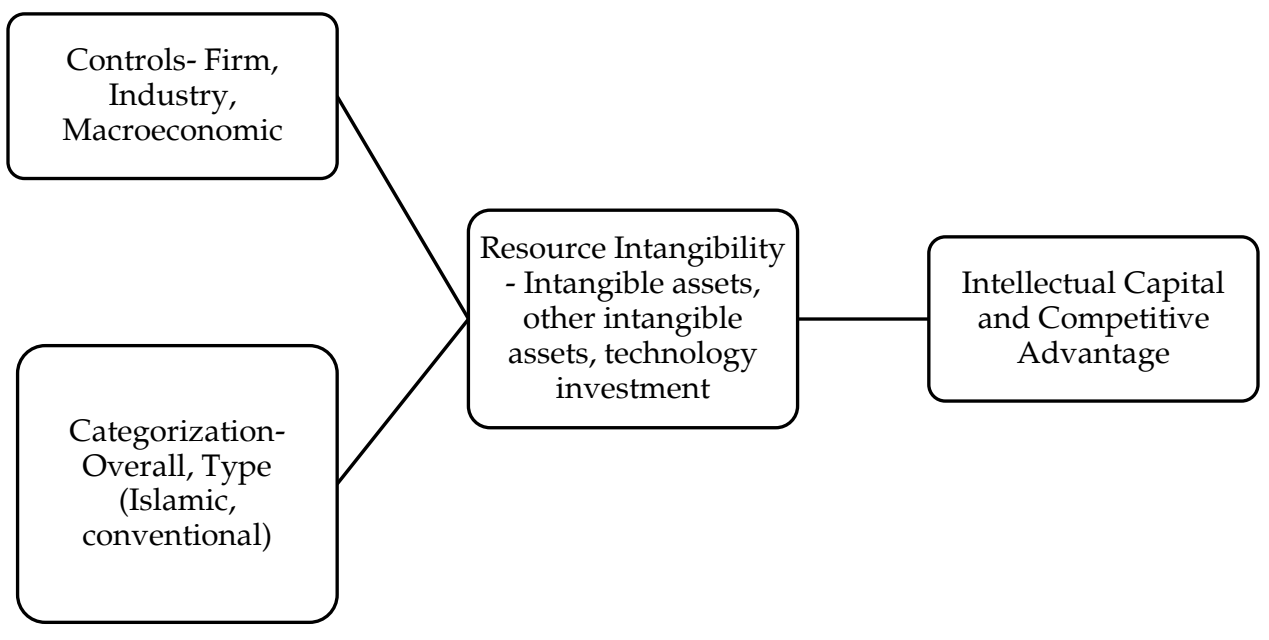

\section{Literature Review and Theoretical Framework}

\subsection{Resource Intangibility - Understanding IAS 38}

The objective of the IAS 38 is to prescribe the accounting treatment for the intangible assets that are not dealt with specifically in another IFRS. This standard defines the intangible assets as "an identifiable nonmonetary asset, without any physical substance. An asset is a resource that is controlled by the entity as a result of the past events (for example, purchase or self-creation), and from which certain future economic benefits (inflows of cash, or other assets) are expected [IAS 38.8].

On this basis, the standard further elaborates that three key attributes must be present for an asset to be categorized as intangible. That is to say that, first, it must be identifiable (separate and contractual). Second, the firm must have control of the asset, to the extent that it has the authority to derive advantages from that particular asset. And lastly, it 
must generate some form of advantage for the future benefit, either by reducing future costs or by providing future revenues.

As per the standard, intangibles we the include patented technology, computer software, databases and trade secrets, trademarks, domains, licensing, royalty and standstill agreements, etc. These intangible assets can be acquired through a separate purchase or business acquisition, the exchange of assets, government grants or internal generation of funds.

\subsection{Measuring intangible assets}

An "Intangible" asset is a rather broad term, and therefore, in order to assess its impact on a firm's performance and productivity, it is essential to define intangible assets in an accurate manner. When studying the existing literature, there seem to be two main methods that emerge for this purpose. These include the categorization by proxies, and the balance sheet measures. The categorization by proxies is done in two ways. Some researchers choose to identify intellectual capital as a primary form of intangible assets, and make further subdivisions which include partitioning into human capital, structural capital, and one or more of the additional forms of relational capital (Sveiby, 1997). The underlying logic of this approach is that the development of intangible assets is concurrent to the knowledge acquisition, implementation, and subsequent tangible asset development, in a cyclical process

When considering the tangible assets, a firm simply accounts for the various categories of assets, and reports them accordingly. However, research shows that more and more value is derived from intangible assets, especially in the chemical, pharmaceutical, and the IT-oriented sectors. The reason for this happening is that, this is precisely where the observable growth in the market value is not sustained by the tangible assets alone. Previously, the investments in intangible assets were expensed rather than depreciated. This caused subsequent issues when taking into consideration, the long term projects, or high growth industries (Anthony \& Reece, 1983; Lev, 1999). Over time, this accounting treatment tends to become one of the main causes for liquidity problems, as the healthier firms with strong prospects face higher costs of capital. Therefore, this realization necessitated a revision of the policy. Hence, the intangibles were no longer to be expensed; rather, they were to be amortized like their tangible counterparts. 
The Existing literature that is developed on the behavior of the intangible assets analyzes both the profitability, and performance that is associated with them. However, its contribution to the differences in profits remains relatively unexplored. Some research that is on the profit persistence identifies the need to explore the underlying factors that are responsible for this perseverance in performance (McGahan \& Porter, 1999, 2003; Mueller, 1977, 1986). Further research has shown that the causes of profitability may not necessarily contribute to its persistence, specifying that the firm-specific factors must be explored, rather than the dwelling into the industry-specific factors (Cubbin \& Geroski, 1987; Jacobsen, 1988).

The emerging-market crisis of 1997/98 showed that the ownership structures were considered to be fundamental, in order to reroute the cash resources (Jian \& Wong, 2010). In this regard, Johnson et al. (2000) suggested controlling the stakeholders' benefits from the asset sales or through the purchases that take place in the European market. Thus, keeping this trend in consideration, it becomes necessary to determine the impact of these transactions on the firms' financial performance. This is especially relevant in terms of taking cues from the earlier studies that have examined the incentives underlying the corporate decisions, in order to pursue certain types of RPTs (Watts \& Zimmerman, 1986). Several studies have analyzed how the volume of the RPTs affects the management of the earnings (DeAngelo, 1988; Jones, 1991; Teoh, Welch \& Wong, 1998a, 1998b), and then review the preceding implications for the accounting standard setters and regulators (Healy \& Wahlen, 1999).

\subsection{Resource Intangibility and Firm Performance}

Intangible assets are valued according to their intellectual, and legal right, and serve the function of value-addition to the other tangible assets. They were initially considered difficult to identify, and categorize (Conner \& Prahalad, 1996; Kogut \& Zander, 1992). Research also shows that intangible assets served their true purpose in the imperfect factor markets (Barney, 1996), and also exhibited complementarities to them (Athey \& Stern, 1998; Milgrom et al., 1991; Rivkin, 2000). The ultimate consequence of this was a classification of the assets that were both difficult to obtain, develop, and replicate (Itami, 1987; Winter, 1987). Thus, these characteristics contributed towards a competitive edge for some firms (Dierickx \& Cool, 1989; Nelson, 1991; Rumelt, 1984). This uncertain imitability is what makes the intangible assets valuable, and prone to be the basis of sustainable competitive advantage for a firm (Lippman \& Rumelt, 1982; Hall, 1993b). 
It is not possible to completely, and comprehensively understand the implications of the intangible assets on the firms' performance and the competitive advantage that is offered, without taking into context the Resource-Based View (RBV). This theory tends to indicate that all the resources that a firm possesses, have ultimately contributed towards its true value. This further indicates that if some portion of the value cannot be matched by the tangible assets, then it is naturally determined by the intangible assets. The combination of the tangible and intangible assets contributes towards the sustainability of the performance that a firm exhibits. A fundamental drawback of this perspective is that, in this form it is very challenging to operationalize and test its true effectiveness. For example, it is nearly impossible to identify the extent of the impact that the industry factors have on the firms' performance. Moreover, it also becomes necessary to segregate the tangibles and the intangibles, in relative proportion, in order to understand their contribution to the performance of the firm.

When considering the RBV as the underlying presumption of the determinants of firm performance, all the resources, that pertain to the implicit knowledge and understanding of the business, and the real activities and the interdependencies of the implicit and explicit resources, are considered to be characteristics that can be expected to translate into a greater degree of intangibility of the firm's resources. Furthermore, the inimitability is, in turn, responsible for the greater sustainability that is expected under the RBV umbrella.

If the intangible assets help to sustain the differences in the firm performance, across firms, by enhancing the sustainability of competitive advantage, the competitive disadvantages must either stay constant, or also persist in time. Extant research has been analyzing the role of the RBV, in the sustainability of the firms' performance. This literature shows that, the asset composition contributes towards a competitive disadvantage, just as much as it contributes to the competitive advantage. In this regard, research also shows that existing capabilities that contribute to firm performance can be eradicated with radical innovation (Henderson \& Clark, 1990). From another perspective, Leonard-Barton (1992) identifies those aspects of the core capabilities that primarily hinder innovation and the development of intangibles in a firm.

\subsection{Industry effects on the impact of intangibles on sustainability}

In the existing literature on the intangible assets, the resource-based perspective recognizes that the sustainability of a firm's performance 
differs in terms of the utility of the intangible assets. This can be attributed to various underlying factors. When considering the industry as a factor of difference, it is essential to note that the utility of the intangible assets, as a source of competitive advantage, will differ significantly across the industries, mainly due to the nature of their business. Also referred to as the strategic industry factors, these resources represent the benchmark for the industry participants (Amit \& Shoemaker, 1993). When considering the firm characteristics, an individual organization's ability to efficiently utilize tangible, and intangible assets, in order to maintain a competitive edge, is as essential as ensuring that the industry-specific strategic factors are prevalent for the sustainability of the firms' performance.

Secondly, it is necessary to note that the efficient utilization of the intangible assets varies due to their existence, operation and contribution at various levels within the firm. RBV identifies that the intangible assets may exist at operational levels, as processes or projects, or at resource levels, such as functions, teams, or employees (Grant, 1991; Nelsons \& Winter, 1982). Most of the analysis of the intangible assets, based on the resource perspective, does not differentiate between the firm as a whole and these sub-divisions have been created to analyze the role of each function in isolation (Nelson, 1991; Rumelt, 1991). Some industries may require the appropriation of specific areas of intangibles, thereby affecting the efficiency and utility across the various industries, differently. This has also been explored by Levin et al. (1987) who discovered that the proportion of the return to $R \& D$, varies significantly across the industries.

\section{Methodology}

This research will utilize the secondary data that has been extracted from the annual reports of the commercial banks that are listed on the primary stock exchange of Pakistan (PSX). The time frame for the analysis will be from FY2008-FY2018. The eleven-year time frame will allow for the adequate observations, so as to study the various aspects that have been proposed in the research objective. As no centralized database exists, therefore, it must be collected from the company annual reports. Moreover, this study will use the panel data analysis, in order to determine the econometric methodology, as per the nature of the data and variables. The sample size will allow the researcher to determine the prevalence of the intangible assets over a period of time.

The independent variable in this study is the resource intangibility, while the dependent variables are the intellectual capital and the 
Competitive Advantage in Banking

competitive advantage. For the robustness, we have tested the impact of the resource intangibility, on the standard banking performance measures, such as Tobin's $Q$, and CAMELS. Furthermore, the control variables in this study include the firm-level controls (leverage, firm size), industry controls (concentration $\mathrm{HHI}$ ), and the macroeconomic controls (GDP per capita).

\subsection{Variable Description}

\subsubsection{Independent Variables}

\subsubsection{Resource intangibility}

The extant research available on this aspect of company asset analysis, utilizes two main methods of identifying intangible assets. The first one of these is based on the R\&D expenditures, training and the innovation expenditures, while the second one is pertaining to the intangible assets that are listed on the balance sheet (Bontempi \& Mairesse, 2008). Therefore, the study will utilize the balance sheet measures of the intangible assets, with a specific reference to the various associated standard measures such as the International Accounting Standards (IAS), and the International Financial Reporting Standards (IFRS).In doing so, we differ from the existing literature of this area. According to the standards:

IAS 38 Intangible Assets outlines the accounting requirements for intangible assets, which are non-monetary assets that are without physical substance and identifiable (either being separable or arising from contractual or other legal rights). Intangible assets meeting the relevant recognition criteria are initially measured at cost, subsequently measured at cost or using the revaluation model, and amortized on a systematic basis over their useful lives (unless the asset has an indefinite useful life, in which case it is not amortized)." This approach has been selected, as the economies in the sample use either the IFRS standards, or the national accounting standard, that is derived from the IFRS. It also follows the variables, as they have been identified in the studies put forth by Arrighetti et al. (2014) and Villalonga (2004).

This measure is used to represent the intangible capital intensity of the firm, and is calculated as a percentage of the intangible assets, divided by the total assets. This means, that at any point in time, it represents a proxy of intangible assets that are accumulated by the bank. The intangible asset investment (IAI) is measured as the change in the intangible assets, from one year to the next - that is to say, that this measure will 
simultaneously account for the amortization of the existing intangible assets, as well as the new investments in the intangible assets, and represents a crucial variable in our analysis.

Table 1: Independent Variables

\begin{tabular}{lll}
\hline Variable & Formula & Reference \\
\hline Intangible Assets - IA & Intangible & Arrighetti et. al. (2014), \\
& Assets/Total Assets & Villalonga, (2004) \\
Intangible Asset & (IAt-IAt-1)/IAt-1 & Arrighetti et. al. (2014) \\
Investment - IAI & & Villalonga (2004) \\
$\begin{array}{l}\text { Other Intangible } \\
\text { Assets -OIA }\end{array}$ & $\begin{array}{l}\text { Intangible Assets } \\
\text { other than }\end{array}$ & Author's calculation \\
\hline
\end{tabular}

Ghemawat (1991) proposes a specific vehicle through which the characteristics of the intangible resources translate into the sustainability of the competitive advantages for the firms. In his view, the intangible assets, because of their lower trade-ability and higher stickiness, are particularly prone to be a source of commitment, which he defines as the tendency of the strategies to persist over time. Commitment, in turn, is "the only general explanation for sustained differences in the performance of organizations". If the intangibles help sustain the performance differences across firms, by enhancing the sustainability of the competitive advantage, the competitive disadvantages must either stay constant, or also persist during the course of the time. Some RBV studies indicate that the latter is in fact the case. Henderson and Clark (1990) argue that the radical innovation destroys the usefulness of the firms' existing capabilities, or in other words, the "architectural knowledge". Leonard-Barton (1992) coined the term "core rigidities" in order to refer to the innovation-inhibiting downside of the core capabilities. Christensen (1993) describes how the know-how, and the customer base that gave certain hard disk drive manufacturers a competitive advantage, eventually became the liabilities that led them to be displaced by a newer generation of firms.

\subsubsection{Control Variables}

The Control Variables include three categories - the firm-level, industry level, and the country-level controls. The firm-level controls include the size and leverage. Whereas, the Industry-level control is the concentration ratio, and the country-level control is the GDP per capita. 


\subsubsection{Bank Size}

The bank size is generally used to measure the economies or diseconomies of scale in the banking sector. For the purpose of this study, we assume that as the bank size becomes larger, it would become more stable. The cost differences may cause a positive relationship between the size and the bank's performance, especially if there are significant economies of scale present (Bourke, 1989; Goddard et al., 2004; Molyneux \& Thornton, 1992). Also, as Short (1979) argues, the size of the bank is closely related to its capital adequacy, since relatively larger banks tend to raise less expensive capital and, hence, appear to be more profitable. In the previous extant literature, some studies have found the existence of the scale economies for large banks (Berger \& Humphrey, 1997; Altunbaş et al., 2001; Athanasoglou et al., 2006; Zopounidis \& Kosmidou, 2008), while the others have found diseconomies for larger banks (Kosmidou et al., 2005; Pasiouras \& Kosmidou, 2007). However, Eichengreen and Gibson (2001) indicated that the effect of a growing bank's size on the profitability may be positive, only up to a certain limit. Beyond this point, the effect of the size could be negative due to the bureaucratic intricacies that exist. Thus, the relationship may be expected to be non-linear. Therefore, like the previous studies, we use the natural logarithm of the bank's total assets (SIZE) as a proxy for the size.

\subsubsection{Leverage}

Literature addressing capital structure of financial sector is scarce owing to capital regulations view; claiming that capital regulation requirement is the prime determinant of capital structure in financial sector. Ftiti et. al. (2013) and Trad et. al., (2017) find that leverage has a significant impact on firm performance. Therefore, like previous studies, we use the ratio of total liabilities to total asset (LEV) as a proxy for leverage.

\subsubsection{Concentration Ratio}

Regarding the industry concentration, we have referred to the Herfindahl Hirschman Index. The Herfindahl-Hirschman Index (HHI) is a commonly accepted measure of market concentration. It is calculated by squaring the market share of each firm that is competing in a market, and then summing the resulting numbers. Also, it can range from close to zero to 10,000. Besides, the higher the value is, the lesser competition they have. According to the structure-conduct-performance (SCP) hypothesis, the 
banks in highly concentrated markets tend to collude, and thus, ted to earn monopoly profits (Gilbert, 1984; Molyneux et al., 1996; Short, 1979). The previous studies have indicated that the collusion may cause the higher interest rates to spread (higher interest rates being charged on the loans and the lower interest rates being paid on the deposits), and also, a higher fees being charged (Goddard et al., 2011; Goldberg \& Rai, 1996).

\subsubsection{GDP per Capita}

In order to capture the effect of the macroeconomic environment, the macroeconomic variable used in this study is the annual GDP per capita (GDP). The GDP is a measure of the total economic activity within an economy. The higher economic growth encourages the banks to lend more, and permits them to charge higher margins, therefore, improving the quality of their assets. Previous studies have revealed that the economic growth has a positive effect on a bank's performance (Athanasoglou et al., 2008; Kosmidou et al., 2005; Kosmidou, 2008; Pasiouras \& Kosmidou, 2007). Thus, the GDP is expected to have a positive impact on bank performance.

\section{Table 2: Control Variables}

\begin{tabular}{lcc}
\hline \multicolumn{1}{c}{ Variable } & Formula & Reference \\
\hline Size of the firm - Size & lnTotal Assets & Ftiti et. al. (2013) \\
& & Trad et. al., (2017) \\
$\begin{array}{l}\text { Level of leveraging of a } \\
\text { firm - Lev }\end{array}$ & Total & Ftiti et. al. (2013) \\
& liabilities/Total & Trad et. al., (2017) \\
$\begin{array}{l}\text { Concentration within } \\
\text { the industry - Conc }\end{array}$ & Assets & \\
GDP per capita - GDP & Hirshman Index) & Ftiti et. al. (2013) \\
& & Trad et. al., (2017) \\
& & Ftiti et. al. (2013) \\
& & Trad et. al., (2017) \\
\hline
\end{tabular}

\subsubsection{Dependent Variables}

\subsubsection{Value Added Intellectual Capital}

Pulic (2000) quantifies the value addition from the components of the intellectual capital, as well as the physical capital. He proposed the VAIC model, which accounts for the total resource base of the organizations, and does not solely rely on the physical capital Possessed by the firm. 
The first step in calculating the VAIC involves quantifying the value addition, which is the difference between the output, measured as the sales revenue, and the input, measured as the total operational expense, excluding the employees' cost.

$\mathrm{VA}=$ output - Input

The second step involves calculating the human capital. In his study, Pulic (2000) uses the total employee cost as the best proxy for human capital.

$\mathrm{HC}=$ Total Employee cost

The next step refers to quantifying the value addition from each unit of the employee cost.

$\mathrm{HCVA}=\mathrm{VA} / \mathrm{HC}$

The fourth step involves quantifying the value addition from the structural capital. The Structural capital is obtained by deducting the total employee costs from the value addition.

$\mathrm{SC}=\mathrm{VA}-\mathrm{HC}$

Since the structural capital and the human capital have an inverse relationship, the value-added efficiency of the structural capital is quantified in a slightly different manner as compared to thevalue-added efficiency of the human capital.

$\mathrm{SCVA}=\mathrm{SC} / \mathrm{VA}$

Now that the value-added efficiency of the human, as well as the structural capital is quantified, adding both of these variables together gives the value-added efficiency of the intellectual capital.

$\mathrm{ICVA}=\mathrm{HCVA}+\mathrm{SCVA}$

Once the value-added efficiency of the physical capital is calculated, the sum of both the variables will be used to measure the valueadded efficiency that is derived from the firms' complete resource base. Therefore, the physical capital is calculated as the total net assets, less any intangible assets. 
PC $=$ Non-Current Assets + Current Assets - Intangible Assets - Current Liabilities

The value-added efficiency of the physical capital is quantified in the same way as that of the value-added efficiency of the human capital.

$\mathrm{PCVA}=\mathrm{VA} / \mathrm{PC}$

Thus VAIC is the sum of the value added efficiency of the physical capital, structural capital, as well as the human capital.

$\mathrm{VAIC}=\mathrm{PCVA}+\mathrm{ICVA}$

\subsubsection{Competitive Advantage}

A firm's competitive advantage (disadvantage) is the degree to which it outperforms (underperforms) its competitors. If the performance is measured by the profitability, the difference between a firm's profitability, and the average profitability of its industry is thus a direct indicator of its competitive advantage. The Positive sign represents a position of advantage, while the negative sign represents a position of disadvantage (Villalonga, 2004).

Table 3: Dependent Variables

\begin{tabular}{|c|c|c|}
\hline Variable & Formula & Reference \\
\hline $\begin{array}{ll}\text { Intellectual Capital } \\
\text { VAIC }\end{array}$ & $\begin{array}{c}\text { VAIC }=\text { PCVA }+ \text { SCVA }+ \\
\text { HCVA }\end{array}$ & Pulic (2000) \\
\hline $\begin{array}{l}\text { Competitive Advantage } \\
\text { - ComAdv }\end{array}$ & ROAco - AvgROAind & $\begin{array}{l}\text { Villalonga } \\
(2004)\end{array}$ \\
\hline
\end{tabular}

\subsection{Robustness Analysis - Dependent Variables}

\subsubsection{Tobin's $Q$}

It is no surprise that a company's primary goal is to maximize its profits- this concept is often used synonymously with the shareholders' wealth maximization (Husnan, 2002). These two goals are applied simultaneously, in the sense that, as the value of a company increases, it will logically position itself in a higher tier with an increase experienced in its share value, which translates into a benefit for the shareholder. The wealth of the shareholders and the companies is represented by the market price of its shares, which are a reflection of the investment decisions, funding 
Competitive Advantage in Banking

(financing), and the asset management that has taken place in the company. Therefore, we use Tobin's $Q$ as a dependent variable in this study, in order to measure the performance quotient. Tobin's $Q$ is calculated by comparing the ratio of the market value of the company shares, with the book value of the company equity (Smithers \& Wright, 2007).

\subsubsection{CAMELS}

Although a non-unique set of indicators exist, the CAMELS indicators appear to have a significant capacity to assess the soundness of the bank, with the combination of the indicators (Wanke et al. 2016). Therefore, for the purpose of this study, we have adopted the CAMELS combination as a proxy of the financial stability. The financial dimensions of this combination are employed by the regulators and the supervisors, in order to assess the banks' overall health (Avkiran \& Cai, 2012; Buch et al., 2016; Calabrese et al., 2017; Klomp \& De Haan, 2012; Wanke et al., 2015; Wanke et al., 2016). However, the original criteria of the categories of the CAMELS ratings are undisclosed and unavailable to the public. Hence, the proxy of each category is selected based on the data availability and the prior studies (Avkiran \& Cai, 2012; Jin et al., 2011; Wanke et al., 2016).

The components of the CAMELS are as follows: the Capital adequacy $(\mathrm{C})$ is captured by the total equity to the total assets, and is treated as a desirable output. Ideally, it should be maximized when, more equity is conducive to less financial distress. The asset quality (A) is captured by the ratio of the non-performing loans (NPLs) to the total loans, which is an undesirable input, and should ideally be minimized. Similarly, the management efficiency $(\mathrm{M})$ acts as a proxy in the form of the operating assets to the total assets, and is regarded as an undesirable input. However, the quality of the earnings (E) has a proxy in the form of the return on assets (ROA), whereas, the return on equity (ROE) is maximized as a desirable output. Moving further, the liquidity (L) is another desirable output that has a proxy in the form of liquid assets, to the short term liabilities. The sensitivity to the market risk (S) is measured by the ratio of the bank assets to the sector assets, as they are treated as a desirable output, because of the role of the total assets in impeding the default risk (Dincer \& Dincer, 2013; Ghasemi \& Rostami, 2015; Wanke et al., 2016).

All these robustness variables are described in Table 4 . 
Table 4: Dependent variables for Robustness Check

\begin{tabular}{|c|c|c|}
\hline Variable & Formula & Reference \\
\hline Tobin's Q - TQ & $\begin{array}{c}\text { MV of Assets/BV of } \\
\text { Assets }\end{array}$ & $\begin{array}{c}\text { McGahan }(1999,2003, \text { Lang } \\
\text { \& Stulz }(1994)\end{array}$ \\
\hline Capit & Equity to total assets & $\begin{array}{l}\text { Ghasemi \& Rostami (2015) } \\
\text { Dincer et. al, (2011) }\end{array}$ \\
\hline Asset management - A & NPLs to total loans & $\begin{array}{c}\text { Ghasemi \& Rostami (2015) } \\
\text { Dincer et. al, } 2011\end{array}$ \\
\hline $\begin{array}{l}\text { Management quality - } \\
\text { M }\end{array}$ & $\begin{array}{c}\text { Operating assets to total } \\
\text { assets }\end{array}$ & $\begin{array}{c}\text { Ghasemi \& Rostami (2015) } \\
\text { Dincer et. al, } 2011\end{array}$ \\
\hline Earnings1 - E1 & ROA $=$ Net Income $/$ Total & Ghasemi \& Rostami (2015) \\
\hline Earn & $\begin{array}{c}\text { ROE }=\text { Net Income } / \text { Total } \\
\text { Equity }\end{array}$ & Dincer et. al, 2011 \\
\hline Liquidity - L & $\begin{array}{l}\text { Liquid assets to short } \\
\text { term liabilities }\end{array}$ & $\begin{array}{r}\text { Ghasemi \& Rostan } \\
\text { Dincer et. al, } 2\end{array}$ \\
\hline Sensitivity - S & $\begin{array}{c}\text { Bank assets to sector } \\
\text { assets }\end{array}$ & $\begin{array}{c}\text { Ghasemi \& Rostami (2015) } \\
\text { Dincer et. al, } 2011\end{array}$ \\
\hline
\end{tabular}

\subsection{Model:}

- For H1a

$$
\begin{aligned}
& \text { VAIC }=\alpha_{i}+\beta_{0} \text { VAIC }_{i t-1}+\beta_{1} \text { IAIB }_{i t}+\beta_{2} \text { Controls }_{i t}+\varepsilon_{i t} \\
& \text { ComAdv }=\alpha_{i}+\beta_{0} \text { ComAdv }_{i t-1}+\beta_{1} \text { IAIB }_{i t}+\beta_{2} \text { Controls }_{i t}+\varepsilon_{i t}
\end{aligned}
$$

- For H1b

VAIC $=\alpha_{i}+\beta_{0}$ VAIC $_{i t-1}+\beta_{1}$ IAIB $_{\text {it }}+\beta_{2}$ Controls $_{\text {it }}+\varepsilon_{\text {it }}$

ComAdv $=\alpha_{i}+\beta_{0}$ ComAdv $_{i t-1}+\beta_{1}$ IAIB $_{i t}+\beta_{2}$ Controls $_{i t}+\varepsilon_{i t}$

VAIC $=\alpha_{i}+\beta_{0}$ VAIC $_{\text {it }-1}+\beta_{1}$ IACB $_{\text {it }}+\beta_{2}$ Controls $_{\text {it }}+\varepsilon_{\text {it }}$

ComAdv $=\alpha_{i}+\beta_{0}$ ComAdv $_{i t-1}+\beta_{1}$ IACB $_{\text {it }}+\beta_{2}$ Controls $_{\text {it }}+\varepsilon_{\text {it }}$

The equations represent the dynamic panel data model (Anderson \& Hsiao, 1982), where a fixed effect approach is utilized in order to account for the potential correlation of the regressor (IA) with the firm-specific components of the error term. This is done, so as to account for all those intangibles that may not be explicitly indicated in the accounting variable, but would still affect the outcome. This potential correlation may result in a Nickell bias (Nickell, 1981). There are three possible solutions to this problem - the first solution is to take the deviations from the firm means, and correct the OLS estimates using the original formula (McGahan \& Porter, 1999; Waring, 1996). Alternatively, it is possible to use the firstdifferencing, so as to eliminate the intercept and incorporate the lagged 
Competitive Advantage in Banking

exogenous regressors $(\Delta \mathrm{Xt}-1, \Delta \mathrm{Xt}-2, \ldots)$ and the predetermined variables $(\Delta y \mathrm{t}-2, \ldots$, or $\mathrm{yt}-2, \ldots)$ as instruments for the lagged dependent variable $(\Delta y t-1)$ (Anderson\& Hsiao, 1982). Finally, it is also possible to use the generalized method of moments (estimator) (Arellano \& Bond, 1991; Arellano \& Bover, 1995). This method has proven to have higher levels of efficacy, in comparison to the other two alternatives. In the panel data research, determining the impact of various firm-specific factors on the value and performance of a firm, the GMM estimator has proven to be the most appropriate method for estimation. In this study, since the primary purpose is to test the proposed hypothesis, therefore, the efficiency considerations are paramount.

\section{Results and Discussion}

Appendix Table 5 reports the descriptive statistics for the intellectual capital performance, and the independent variables selected in this study. The mean intangible assets in the banking sector are 0.039 , while the other intangible assets, and intangible asset investment for the sample banks throughout the study period are 0.0049 , and 11.50, respectively. The independent variables represented by the VAIC (along with its subcomponents HCVA, SCVA, ICVA, and PCVA) and the competitive advantage, all vary as well, and this should increase the confidence level in the results as argued by Naser and Al-Khatib (2000).

The factor of multicollinearity exists when the independent variables correlate significantly with each other. The multicollinearity in the data set was investigated by the correlation matrix of the independent variables that are shown in Appendix Table 6. The highest correlation coefficient value came out to be between the HCVA and the Competitive Advantage, and was less than 0.99 (it is 0.78), which means that the multicollinearity should not be considered as acritical factor as argued by El-Bannany (2002). Furthermore, Neter, et. al. (1985) stated:

"[.. .] propagated the fact that if some, or all independent variables are correlated among themselves, it does not, in general, inhibit our ability to obtain a good fit, nor does it tend to affect the inferences about the mean responses or predictions of new observations. This condition applies, provided these inferences are made within the region of the observations.

Moreover, Neter (1985) also stated that "deleting some variables to reduce multicollinearity reduces the model's explanatory power and may lead to specification errors". 
An initial analysis of the mean resource intangibility and the intellectual capital profiles of the banks across the selected time frame (see Appendix Figure 2 - Figure 9), helps to identify the basic patterns that can be expected.

When taking into account Pakistani banks, we can concur that Bank Al Habib Limited has the highest mean exposure to insolvency risk, while Summit Bank, SilkBank, and the Bank of Punjab have the lowest mean exposure to insolvency risk (see Figure 2). Furthermore, Samba Bank has the highest mean exposure to the credit risk1, while the Bank of Punjab, Askari Bank, and Bank AlFalah Limited have the lowest mean exposure to credit risk1 (see Figure 3). Additionally, Bank Islami and Summit Bank have the highest mean exposure to the credit risk2, while Meezan Bank, Bank AlHabib Limited, and JS Bank have the lowest mean exposure to credit risk2 (see Figure 4). Banks which possess positive competitive advantages are considered to be advantaged, while the banks with negative competitive advantages are considered to be disadvantaged. Moving forward, the Allied Bank, Bank AlHabib Limited, Bank of Khyber, Faysal Bank, Habib Bank Limited, Habib Metropolitan Bank, MCB, Meezan Bank, National Bank, Soneri Bank, and United Bank, all fall under the category of advantaged banks (see Figure 5).

Taking the same concept forward, Meezan Bank has the highest VAIC, while Samba Bank has the lowest VAIC. In the sample that is taken into account, only the BOP and Samba Bank seem to demonstrate a negative VAIC, thereby indicating a serious lack of value addition for these banks (see Figure 6). Besides, Meezan Bank has the highest HCVA, while the BOP has the lowest HCVA. Only the BOP, Samba Bank, and the Summit Bank exhibit a negative HCVA, indicating that the intellectual capital in these firms does not, in fact, contribute towards the process of value addition (see Figure 7). Additionally, the SCVA is the highest for Silkbank and Bank AlFalah Limited; and the lowest for Bank Islami, Habib Metropolitan, and Meezan Bank (see Figure 8). Moreover, Meezan Bank also has the highest ICVA, directly as a result of the high levels of the HCVA and the SCVA. Only the BOP exhibits a negative mean ICVA, thereby indicating a critical strategic delinquency for this bank (see Figure 9).

The results presented in Appendix Table 7 to Appendix Table 12 show that the various aspects of the regression model are significant, however, a thorough analysis of the intricate interrelationships is still necessary. The overall analysis in Appendix Table 7 shows that the intangible assets or the resource intangibility, and the other intangible 
assets do not have a significant impact on the VAIC. However, it is significant in the HCVA, PCVA, and competitive advantage. The investment in the intangible assets has a negligible, but significant impact on both the PCVA and the competitive advantage.

To further answer our research question, we bifurcated the sample into two categories of banks- the Islamic banks and the conventional banks. Due to the extensively detailed nature of the variables, the Islamic window operations have not been taken into consideration in the final sample. Similarly, in order to maintain a highly balanced sample across our panel data, we only incorporated those full-fledged Islamic banks, which have been operational for at least a period of 5 years. When considering the subcategory of the Islamic banks, the results came out to be very thoughtprovoking (see Appendix Table 8). The intangible assets/resource intangibility is revealed to have a positively significant impact on every aspect of the intellectual capital and the competitive advantage. These results are in line with the previous research (Ghemawat, 1991), which indicates that for Islamic banks, the resource intangibility contributes to the sustainability of the intellectual capital and the competitive advantage. From a managerial perspective, this indicates that the strategic management of the assets, and maintaining a competitive advantage in the Islamic banking system is directly associated with the proportion of intangible assets that the banks have invested into. However, there is a threshold to this - here, more is not particularly merrier, as the intangible asset investment has a consistently negative significant impact on all the aspects of the intellectual capital, as well as a competitive advantage. Surprisingly, while the level of the other intangible assets is very small, and may appear to be insignificant in the preliminary analysis, it also has a consistently negative impact on all the aspects of the intellectual capital, as well as the presence of a competitive advantage. This indicates that the banking institutions should focus on the resource intangibility that is applicable to only the ERP and the IT investments. This is in line with the previous research (Leonard-Barton, 1992) which further enforces the fact that resource intangibility in the intangible assets, other than the ERP and the IT investments for banking, may lead to the innovation inhibiting downside of the core capabilities of a firm. This is further reinforced by an extension on the RBV, which indicates that in some cases - depending on the type of resource intangibility or the speed of innovation, the resource intangibility may destroy the usefulness of the firms' existing capabilities or their architectural knowledge (Henderson \& Clark, 1990). From a managerial and strategic perspective, this indicates that in the banking 
sector, the resource intangibility should be focused upon, when it comes to the need-based investments.

When considering the subcategory of the conventional banks, the results are just as unique (see Appendix Table 9). The intangible assets/ the resource intangibility is completely insignificant to all the aspects of the intellectual capital and the competitive advantage. Other intangible assets have a positive impact on only the HCVA and the PCVA, but a negative significant impact on the competitive advantage that a bank might gain. This reinforces the studies present in the prior literature, and the perspective of the sustainability of the intellectual capital, and the competitive advantage that is achieved through resource intangibility (Ghemawat, 1990). While the contribution of the human capital towards the sustainability is also supported by the RBV, a unique finding of this study shows that the physical capital is just as essential in the banking sector, and may be directly linked to the core function of this sector. The intangible asset investment has a negligible, but significant impact on both the PCVA and the competitive advantage. This indicates that the consistent increases in the resource intangibility over time are necessary, in order to maintain a competitive advantage.

The results also consistently show a reinforcement of the endogenous nature of the intellectual capital, as well as the competitive advantage, which supports the selection of the linear GMM as the method of analysis.

For robustness/comparison sake, we determine the impact of the resource intangibility, on the standard performance measures, including a market-based measure - Tobin's Q (TQ), capital adequacy (C), asset management (A), management quality (M), earning (E1 = ROA, E2 = ROE), liquidity (L), and the sensitivity (S). The overall analysis in Appendix Table 10 shows that the intangible assets/resource intangibility has a positive significant impact on the management quality and the earnings. Other intangible assets have a positive significant impact on Tobin's $Q$, and asset management, but a negative significant impact on the management quality and earnings in terms of the ROA. The intangible asset investment has a negligible but significant impact on the asset management, earnings, liquidity, and the sensitivity.

When considering the subcategory of Islamic banks (see Appendix Table 11), the resource intangibility/intangible assets have a positive significant impact on the management quality and earnings, but a negative 
significant impact on the liquidity, and sensitivity. Other intangible assets have a positive significant impact on the capital adequacy and asset management, but a negative significant impact on Tobin's $Q$, and the earnings. Lastly, the intangible asset investment has a positive significant impact on Tobin's Q, capital adequacy, asset management, and the management quality. However, there is a consistent negative significant impact on the earnings, and liquidity. This variation in the results can be attributed to two factors - resource allocation, and the time it takes to benefit from the resource intangibility. Firstly, whenever investment in intangible assets is made, they require large initial investments, that too with very little prospect of immediate returns. Secondly, as the returns are generated gradually, the initial resource allocation tends to negatively affect both the earnings and liquidity.

When considering the subcategory of conventional banks (see Appendix Table 12), the resource intangibility/intangible assets have a positive significant impact on the capital adequacy and the earnings, in terms of the ROE. Moreover, the other intangible assets have a positive significant impact, in terms of Tobin's $Q$, and asset management, but a negative significant impact in terms of the management quality, and earnings in terms of the ROA. The intangible asset investment has a negligible but significant impact on the asset management, earnings, liquidity, and sensitivity.

The results of the robustness analysis closely mirror those of the initial analysis, with notable exceptions in the Islamic banking sub-category. This indicates that, while the strategic decisions driving the expansion and competitive advantage in conventional banks may be well established, the indications in Islamic banking are very different from what actually is.

\section{Conclusion}

This paper empirically tests the hypothesis that, the resource intangibility, in the form of intangible assets, contributes towards a competitive advantage in the banking sector. Moreover, it determines whether the intangibility of a banks' resources contributes towards the sustainability of the competitive advantage. Finally, it also determines whether the intangible assets contribute towards the banks' performance.

This paper contributes to both the literature and the policy, in three ways. Firstly, it is the first paper to address the prevalence of intangible assets in the banking sector, across a set of developing economies. It is also 
the first of its kind to study the impact of the intangible assets on the intellectual capital and competitive advantage that is specific to this sample. This paper contributes to the practical policy in two ways. Firstly, it will show the prevalence of the intangible assets and the resource intangibility in the banking sector, and their subsequent impact on the intellectual capital and competitive advantage. As such, the policymakers can address which components of the intangible assets and intellectual capital require additional investment, in order to increase the quotient of performance. Secondly, this research also show if, and to what extent, the intellectual capital and competitive advantage affects the risk profiles for the banks.

The findings of this study lead to striking implications for both the Islamic banking theory and the managerial practices in the banking sector. Resource intangibility is to be managed very differently across both the defined categories. Where intangible assets represent a significant contribution to both the intellectual capital and the competitive advantage for Islamic banks, they tend to represent a negligible impact on the intellectual capital and the competitive advantage for conventional banks.

Furthermore, as a measure of performance, they indicate that while the VAIC measures intellectual capital, that too rather well, it may not always be equated with performance, per se. Rather, it is a unique perspective of analysis that must be measured for strategic management purposes. This uniqueness explains a large proportion of the variation in performance results that are attributed to Islamic banks and conventional banks - the performance itself is linked to the intellectual capital foundations which were not included in the prior studies. This also indicates that it is too early to disregard the standard performance measures, especially in the banking sector, where the majority of the market share remains with conventional banks. While Islamic banks have seen an incredible growth and customer acceptance in the last decade, the overall proportion is not yet enough to disregard the longstanding major players in the industry.

Future studies may focus on additional countries, so as to determine the consistency of these patterns. Furthermore, additional explorations are also possible when considering this phenomenon-such as the impact of the bank size, market position, country of location, etc. 


\section{References}

Albaity, M., Mallek, R. S., \& Noman, A. H. M. (2019). Competition and bank stability in the MENA region: The moderating effect of Islamic versus conventional banks. Emerging Markets Review, 38, 310-325.

Albaity, M., Mallek, R. S., \& Noman, A. H. M. (2019). Competition and bank stability in the MENA region: The moderating effect of Islamic versus conventional banks. Emerging Markets Review, 38, 310-325.

AlKhouri, R., \&Arouri, H. (2019). The effect of diversification on risk and return in banking sector: Evidence from the Gulf Cooperation Council countries. International Journal of Managerial Finance, 15(1), 100-128.

Altunbaş, Y., Gardener, E. P., Molyneux, P., \& Moore, B. (2001). Efficiency in European banking. European Economic Review, 45(10), 1931-1955.

Amit, R., \& Shoemaker, P. (1993). Specialized assets and organizational rent. Strategic Management Journal, 14(1), 33-47.

Anderson, T. W., \& Hsiao, C. (1982). Formulation and estimation of dynamic models using panel data. Journal of econometrics, 18(1), 47-82.

Anthony, R. N., \& Reece, J. S. (1983). Accounting: Text and Cases, Richard D. Irwin, Homewood, Illinois.

Arellano, M., \& Bond, S. (1991). Some tests of specification for panel data: Monte Carlo evidence and an application to employment equations. The review of economic studies, 58(2), 277-297.

Arellano, M., \& Bover, O. (1995). Another look at the instrumental variable estimation of error-components models. Journal of econometrics, 68(1), 29-51.

Arrighetti, A., Landini, F., \& Lasagni, A. (2014). Intangible assets and firm heterogeneity: Evidence from Italy. Research Policy, 43(1), 202-213.

Athanasoglou, P., Delis, M., \& Staikouras, C. (2006). Determinants of bank profitability in the South Eastern European region.

Athey, S., \& Stern, S. (1998). An empirical framework for testing theories about complimentarity in organizational design (No. w6600). National Bureau of Economic Research. 
Avkiran, N. K., \& Cai, L. C. (2012). Predicting bank financial distress prior to crises. In New Zealand Finance Colloquium.

Banu Dincer, D., \& Dincer, C. (2013). Corporate governance and market value: Evidence from Turkish banks. International Journal of Academic Research in Business and Social Sciences, 3(1), 2222-6990.

Barney, J. B. (1996). The resource-based theory of the firm. Organization science, 7(5), 469-469.

Berger, A. N., \& Humphrey, D. B. (1997). Efficiency of financial institutions: International survey and directions for future research. European journal of operational research, 98(2), 175-212.

Bontempi, M. E., \& Mairesse, J. (2008). Intangible capital and productivity: an exploration on a panel of Italian manufacturing firms (No. w14108). National Bureau of Economic Research.

Bourke, P. (1989). Concentration and other determinants of bank profitability in Europe, North America and Australia. Journal of Banking E Finance, 13(1), 65-79.

Brown, M., Groen, J., Peristiani, S., \& Snider, A. (2012). Economic policy review. Economic Policy Review, 18(2), 1-94.

Buch, C. M., Koetter, M., \& Ohls, J. (2016). Banks and sovereign risk: A granular view. Journal of Financial Stability, 25, 1-15.

Calabrese, R., Degl'Innocenti, M., \& Osmetti, S. A. (2017). The effectiveness of TARP-CPP on the US banking industry: A new copula-based approach. European Journal of Operational Research, 256(3), 1029-1037.

Carlson, J., Furst, K., Lang, W. W., \& Nolle, D. E. (2001). Internet banking: market developments and regulatory issues. Manuscript, the Society of Government Economists, Washington DC.

Christensen, C. M. (1993). The rigid disk drive industry: A history of commercial and technological turbulence. Business history review, 67(4), 531-588.

Conner, K. R., \& Prahalad, C. K. (1996). A resource-based theory of the firm: Knowledge versus opportunism. Organization science, 7(5), 477-501. 
Corrado, C., Hulten, C., \& Sichel, D. (2005). Measuring capital and technology: an expanded framework. In Measuring capital in the new economy (pp. 11-46). University of Chicago Press.

Corrado, C., Hulten, C., \& Sichel, D. (2009). Intangible capital and US economic growth. Review of income and wealth, 55(3), 661-685.

Cubbin, J., \& Geroski, P. (1987). The convergence of profits in the long run: inter-firm and inter-industry comparisons. The journal of industrial economics, 427-442.

DeAngelo, H., \& Stulz, R. M. (2015). Liquid-claim production, risk management, and bank capital structure: Why high leverage is optimal for banks. Journal of Financial Economics, 116(2), 219-236.

DeAngelo, L. (1988). Discussion of evidence of earnings management from the provision for bad debts. Journal of Accounting Research, 32-40.

DeYoung, R., \& Rice, T. (2004). Noninterest income and financial performance at US commercial banks. Financial Review, 39(1), 101-127.

Dierickx, I., \& Cool, K. (1989). Asset stock accumulation and sustainability of competitive advantage. Management science, 35(12), 1504-1511.

Edirisuriya, P., Gunasekarage, A., \& Dempsey, M. (2015). Bank diversification, performance and stock market response: Evidence from listed public banks in South Asian countries. Journal of Asian Economics, 41, 69-85.

Eichengreen, B., \& Gibson, H. D. (2001). Greek banking at the dawn of the new millennium.

El-Bannany, M. (2008). A study of determinants of intellectual capital performance in banks: the UK case. Journal of intellectual capital, 9(3), 487-498.

El-Bannany, M. A. (2002). Investment in information technology systems and other determinants of bank performance in the UK and Egypt (Doctoral dissertation, Liverpool John Moores University).

Ghasemi, A., \& Rostami, M. (2015). Determinants of interest rate spread in banking industry. International Journal of Applied Research, 1(9), 338-346.

Ghemawat, P. (1991). Market incumbency and technological inertia. Marketing Science, 10(2), 161-171. 
Gilbert, R. A. (1984). Bank market structure and competition: a survey. Journal of Money, Credit and Banking, 16(4), 617-645.

Goddard, J., Liu, H., Molyneux, P., \& Wilson, J. O. (2011). The persistence of bank profit. Journal of Banking E Finance, 35(11), 2881-2890.

Goddard, J., Molyneux, P., \& Wilson, J. O. (2004). The profitability of European banks: a cross-sectional and dynamic panel analysis. The Manchester School, 72(3), 363-381.

Goldberg, L. G., \& Rai, A. (1996). The structure-performance relationship for European banking. Journal of Banking E Finance, 20(4), 745-771.

Grant, R. M. (1991). The resource-based theory of competitive advantage: implications for strategy formulation. California management review, 33(3), 114-135.

Healy, P. M., \& Wahlen, J. M. (1999). A review of the earnings management literature and its implications for standard setting. Accounting horizons, 13(4), 365-383.

Henderson, R. M., \& Clark, K. B. (1990). Architectural innovation: The reconfiguration of existing product technologies and the failure of established firms. Administrative science quarterly, 9-30.

Hulten, C. R., \& Hao, X. (2008). What is a company really worth. Intangible capital and the 'market to book value'puzzles, NBER Working Paper Series, (14548).

Husnan, S. (2001). Corporate Governance and Finance in East Asia. A Study of Indonesia, Republic of Korea, Malaysia, Philphine, and Thailand.

International Accounting Standards Board. (2004). International accounting standards IAS 36, Impairment of assets, and IAS 38, Intangible assets. London: International Accounting Standards Board.

Jacobsen, R. (1988). The persistence of abnormal returns. Strategic management journal, 9(5), 415-430.

Jian, M., \& Wong, T. J. (2010). Propping through related party transactions. Review of Accounting Studies, 15(1), 70-105.

Jin, J. Y., Kanagaretnam, K., \& Lobo, G. J. (2011). Ability of accounting and audit quality variables to predict bank failure during the financial crisis. Journal of Banking E Finance, 35(11), 2811-2819. 
Johnson, S., La Porta, R., Lopez-de-Silanes, F., \& Shleifer, A. (2000). Tunneling. American economic review, 90(2), 22-27.

Jones, J. J. (1991). Earnings management during import relief investigations. Journal of accounting research, 29(2), 193-228.

Khan, T. M., Rizvi, S. K. A., \& Sadiq, R. (2019). Disintermediation of banks in a developing economy: Profitability and depositor protection in adverse economic conditions. Managerial Finance, 45(2), 222-243.

Klomp, J., \& De Haan, J. (2012). Banking risk and regulation: Does one size fit all?. Journal of Banking E Finance, 36(12), 3197-3212.

Kosmidou, K., Tanna, S., \& Pasiouras, F. (2005, September). Determinants of profitability of domestic UK commercial banks: panel evidence from the period 1995-2002. In Money Macro and Finance (MMF) Research Group Conference (Vol. 45, pp. 1-27).

Lang, L. HP \& Stulz Rene, M. 1994., Tobin's Q, Corporate Diversification and Firm Performance. Journal of Political Economy, 1248-1278.

Leonard-Barton, D. (1992). Core capabilities and core rigidities: A paradox in managing new product development. Strategic management journal, 13(S1), 111-125.

Lev, B. (2000). Intangibles: Management, measurement, and reporting. Brookings Institution Press.

Levin, R. C., Klevorick, A. K., Nelson, R. R., Winter, S. G., Gilbert, R., \& Griliches, Z. (1987). Appropriating the returns from industrial research and development. Brookings papers on economic activity, 1987(3), 783-831.

McGahan, A. M., \& Porter, M. E. (1999). The persistence of shocks to profitability. The Review of Economics and Statistics, 81(1), 143-153.

McGahan, A. M., \& Porter, M. E. (2003). The emergence and sustainability of abnormal profits. Strategic organization, 1(1), 79-108.

Mercieca, S., Schaeck, K., \& Wolfe, S. (2007). Small European banks: Benefits from diversification? Journal of Banking and Finance, 31(7), 1975-1998. 
Mercieca, S., Schaeck, K., \& Wolfe, S. (2007). Small European banks: Benefits from diversification?. Journal of Banking $\mathcal{E}$ Finance, 31(7), 1975-1998.

Milgrom, P., Qian, Y., \& Roberts, J. (1991). Complementarities, momentum, and the evolution of modern manufacturing. The American Economic Review, 81(2), 84-88.

Molyneux, P., \& Shamroukh, N. (1996). Diffusion of financial innovations: the case of junk bonds and note issuance facilities. Journal of Money, Credit and Banking, 28(3), 502-522.

Molyneux, P., \& Thornton, J. (1992). Determinants of European bank profitability: A note. Journal of banking E Finance, 16(6), 1173-1178.

Mueller, D. C. (1977). The persistence of profits above the norm. Economica, 44(176), 369-380.

Mueller, D. C. (1986). Profits in the long run. Cambridge University Press.

Naser, K., \& Al-Khatib, K. (2000). The Extent of Voluntary Disclosure in the Board of Directors' statement: The Case of Jordan. Advances in International Accounting, 13, 99-118.

Nelson, R. R. (1991). Why do firms differ, and how does it matter?. Strategic management journal, 12(S2), 61-74.

Nelson, R. R., \& Winter, S. G. (1982). The Schumpeterian tradeoff revisited. The American Economic Review, 72(1), 114-132.

Neter, J., Wasserman, W., \& Kutner, M. H. (1985). Applied linear statistical models: Regression. Analysis of Variance, and Experimental Designs, 2nd Edition, Homewood: Richard D.

Nickell, S. (1981). Biases in dynamic models with fixed effects. Econometrica: Journal of the econometric society, 1417-1426.

Pasiouras, F., \& Kosmidou, K. (2007). Factors influencing the profitability of domestic and foreign commercial banks in the European Union. Research in International Business and Finance, 21(2), 222-237.

Pulic, A. (2000). VAIC ${ }^{\mathrm{TM}}-$ an accounting tool for IC management. International journal of technology management, 20(5-8), 702-714. 
Rumelt, R. P. (1984). Towards a Strategic Theory of the Firm. Competitive strategic management. Competitive strategic management, 556-570.

Rumelt, R. P. (1991). How much does industry matter?. Strategic management journal, 12(3), 167-185.

Short, B. K. (1979). The relation between commercial bank profit rates and banking concentration in Canada, Western Europe, and Japan. Journal of banking $\mathcal{E}$ Finance, 3(3), 209-219.

Smithers, A. Wright. S. (2007). Valuing Wall Street.

Sveiby, K. E. (1997). The intangible assets monitor. Journal of Human Resource Costing $\mathcal{E}$ Accounting, 2(1), 73-97.

Teoh, S. H., Welch, I., \& Wong, T. J. (1998a). Earnings management and the long-run market performance of initial public offerings. The journal of finance, 53(6), 1935-1974.

Teoh, S. H., Welch, I., \& Wong, T. J. (1998b). Earnings management and the underperformance of seasoned equity offerings. Journal of Financial economics, 50(1), 63-99.

Villalonga, B. (2004). Intangible resources, Tobin'sq, and sustainability of performance differences. Journal of Economic Behavior $\mathcal{E}$ Organization, 54(2), 205-230.

Wanke, P., Azad, M. A. K., Barros, C. P., \& Hassan, M. K. (2016). Predicting efficiency in Islamic banks: An integrated multicriteria decision making (MCDM) approach. Journal of International Financial Markets, Institutions and Money, 45, 126-141.

Wanke, P., Barros, C. P., \& Faria, J. R. (2015). Financial distress drivers in Brazilian banks: A dynamic slacks approach. European Journal of Operational Research, 240(1), 258-268.

Waring, G. F. (1996). Industry differences in the persistence of firm-specific returns. The american economic review, 86(5), 1253-1265.

Watts, R. L., \& Zimmerman, J. L. (1986). Positive accounting theory.

Zopounidis, C., \& Kosmidou, K. (2008). The determinants of banks' profits in Greece during the period of EU financial integration. Managerial finance. 
Appendix

Table 5: Descriptive Statistics

\begin{tabular}{lccccc}
\hline Variable & Obs & Mean & Std. Dev. & Min & Max \\
\hline IA & 231 & 0.03987 & 0.08636 & $1.88 \mathrm{E}-07$ & 0.732457 \\
OIA & 231 & 0.004965 & 0.05584 & 0 & 0.846039 \\
IAI & 230 & 11.50162 & 136.6502 & $9.12 \mathrm{E}-05$ & 2071.543 \\
VAIC & 214 & 2.737398 & 3.008855 & -9.23198 & 35.94936 \\
HCVA & 214 & 1.878431 & 1.751211 & -10.1933 & 4.781796 \\
SCVA & 231 & 0.823629 & 2.579706 & -1.79322 & 35.97894 \\
PCVA & 231 & 0.038016 & 0.036401 & -0.13684 & 0.303507 \\
ComAdv & 231 & $-6.67 \mathrm{E}-18$ & 1.323494 & -6.04964 & 3.793561 \\
TQ & 231 & 0.086414 & 0.062828 & 0.010185 & 0.393321 \\
C & 231 & 9.713191 & 7.14068 & -2.8815 & 64.03647 \\
A & 219 & 0.081809 & 0.048778 & 0.011885 & 0.287166 \\
M & 223 & 0.159661 & 0.08043 & 0.042792 & 0.850442 \\
E1 & 231 & 0.814285 & 1.505967 & -6.56372 & 6.093946 \\
E2 & 231 & 8.679952 & 29.73932 & -204.713 & 182.4883 \\
L & 231 & 0.560013 & 0.09853 & -0.03434 & 0.996826 \\
S & 231 & 0.044248 & 0.042374 & 0.000608 & 0.171686 \\
Size & 231 & 12.54439 & 1.176596 & 8.020158 & 14.88329 \\
Lev & 231 & 11.81095 & 13.93093 & -168.216 & 62.47228 \\
Concent & 231 & 931.7509 & 45.42899 & 887.7113 & 1051.621 \\
GDPpercapi e & 211 & 4421.181 & 443.4679 & 3914.612 & 5249.206 \\
\hline
\end{tabular}


Competitive Advantage in Banking

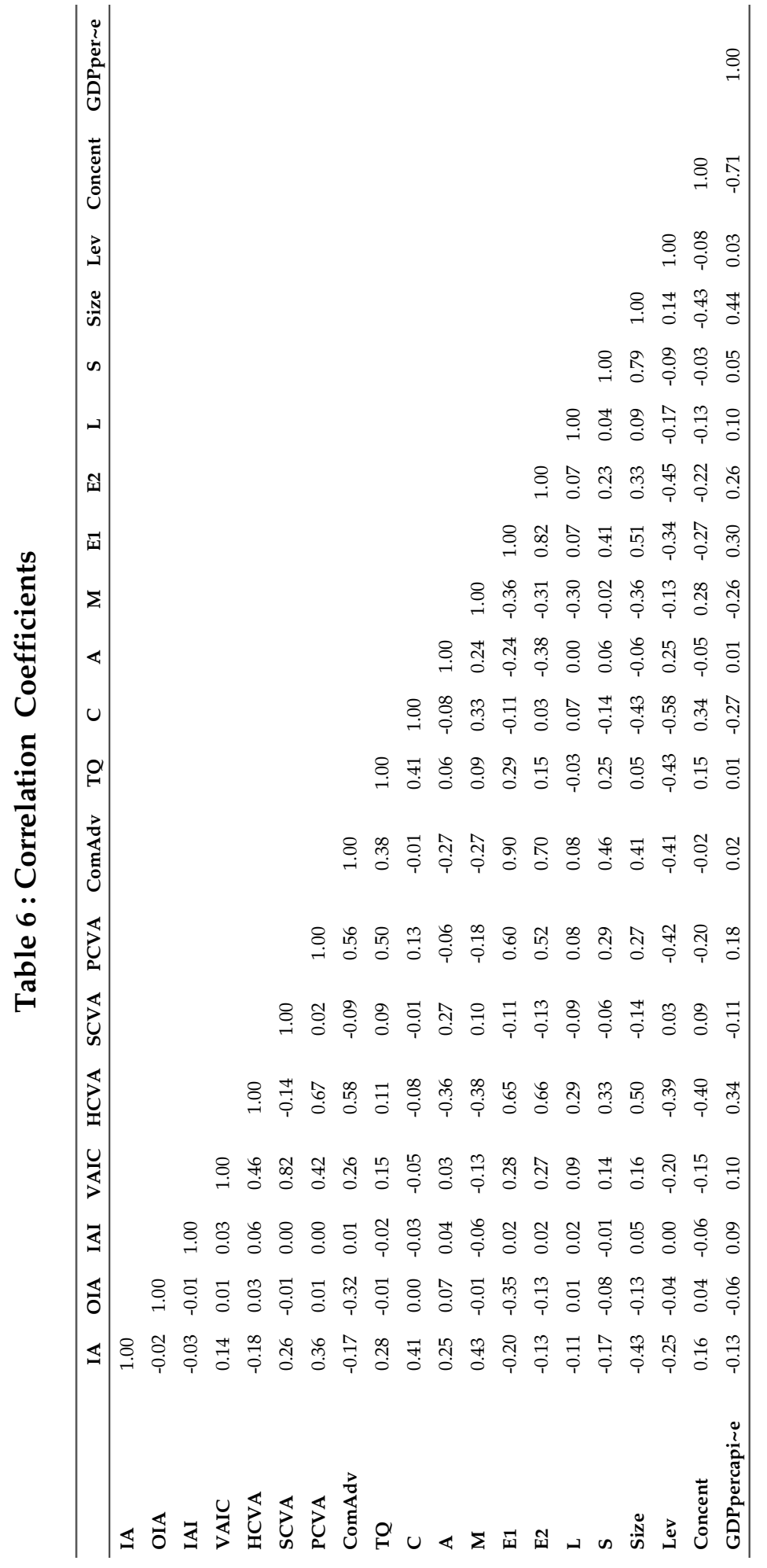


Figure 2: Mean IA

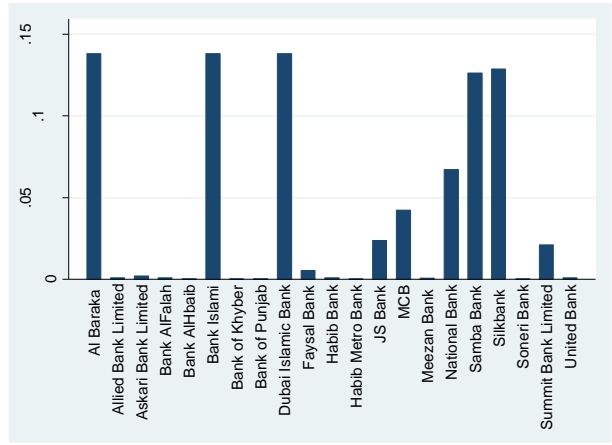

Figure 4: Mean IAI

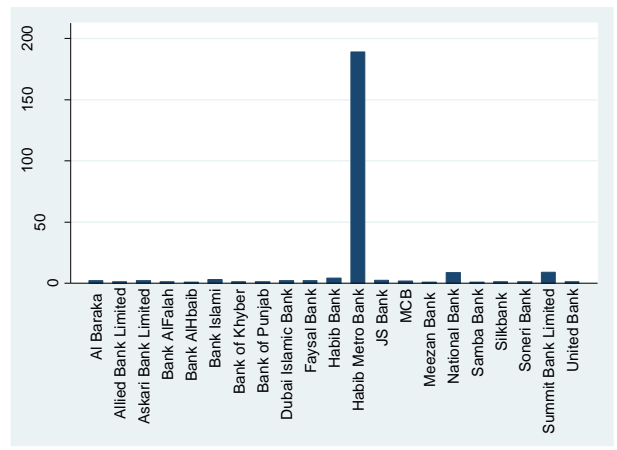

Figure 6: Mean VAIC

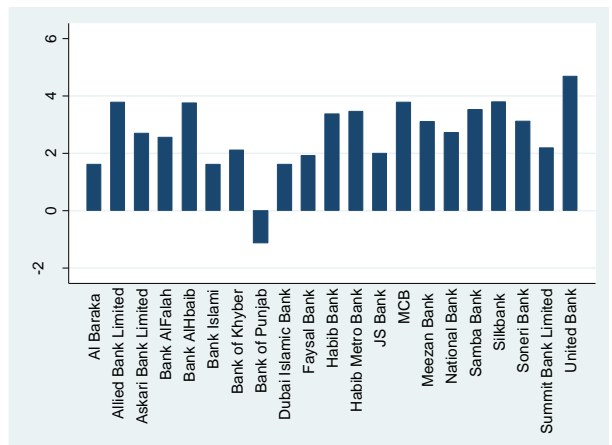

Figure 3: Mean OIA

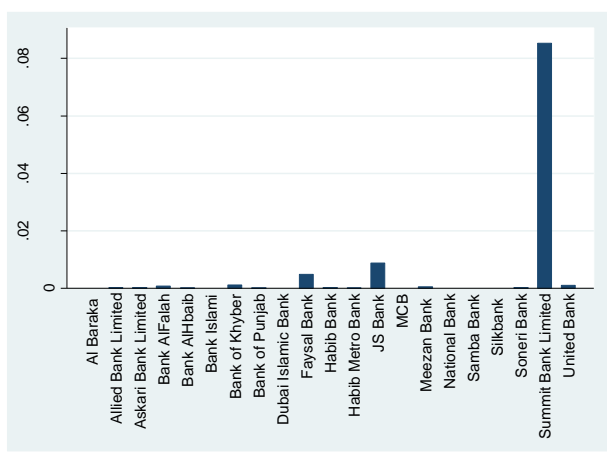

Figure 5: Mean ComAdv

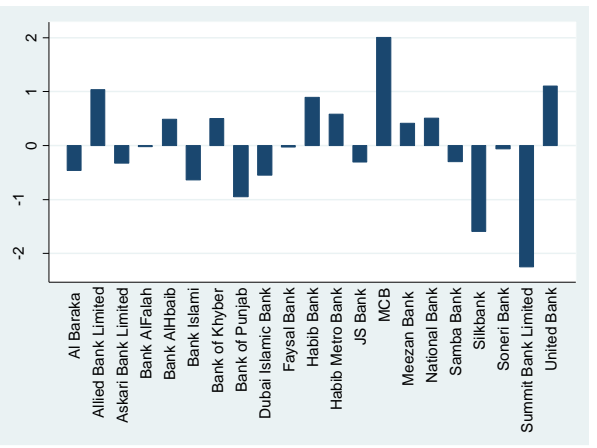

Figure 7: Mean HCVA

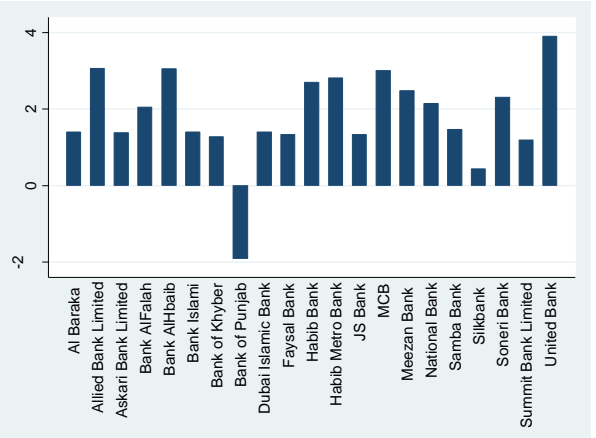


Figure 8: Mean SCVA

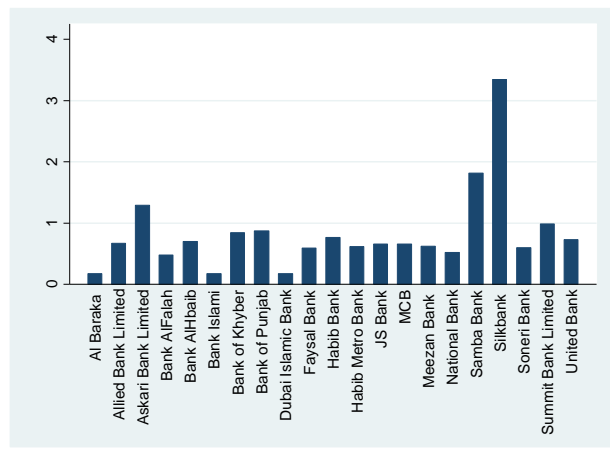

Figure 9: Mean PCVA

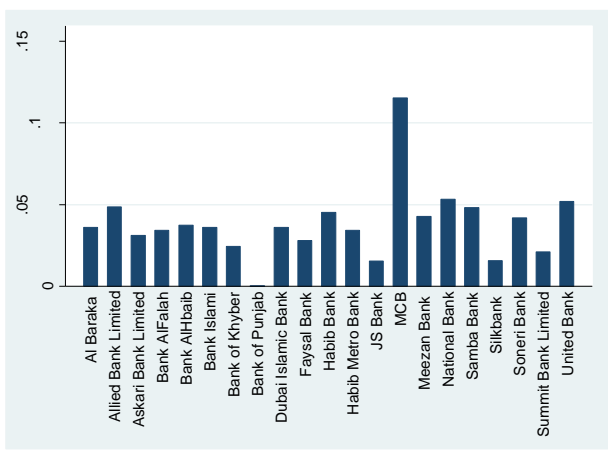

Table 7 : Results - Overall banks

\begin{tabular}{|c|c|c|c|c|c|c|}
\hline & \multicolumn{6}{|c|}{ Overall } \\
\hline & VAIC & HCVA & SCVA & ICVA & PCVA & ComAdv \\
\hline \multirow[t]{2}{*}{ IA } & 0.235 & $1.342^{* *}$ & -0.608 & 0.085 & $0.142^{* * *}$ & $1.037^{* * *}$ \\
\hline & -0.928 & -0.543 & -1.556 & -0.98 & -0.011 & -0.255 \\
\hline \multirow[t]{2}{*}{ OIA } & 2.24 & $6.403^{* * *}$ & -0.768 & 2.027 & $0.129^{* * *}$ & $-4.140^{* * *}$ \\
\hline & -3.992 & -0.647 & -0.641 & -4.114 & -0.009 & -1.244 \\
\hline \multirow[t]{2}{*}{ IAI } & 0 & 0 & 0 & 0 & $-0.000^{* *}$ & $-0.000^{* * *}$ \\
\hline & 0 & 0 & 0 & 0 & 0 & 0 \\
\hline \multirow[t]{2}{*}{ Size } & 0.4 & 0.758 & -1.592 & 0.45 & $0.024^{* * *}$ & 0.433 \\
\hline & -1.381 & -0.766 & -2.316 & -1.366 & -0.007 & -0.298 \\
\hline \multirow[t]{2}{*}{ Lev } & -0.231 & 0.024 & -0.003 & -0.231 & $-0.000^{* * *}$ & $-0.005^{* * *}$ \\
\hline & -0.296 & -0.045 & -0.006 & -0.295 & 0 & -0.002 \\
\hline \multirow[t]{2}{*}{ Concent } & $-0.029^{*}$ & $-0.013^{* * *}$ & -0.019 & $-0.028^{*}$ & $-0.000^{* *}$ & 0.004 \\
\hline & -0.016 & -0.004 & -0.019 & -0.016 & 0 & -0.003 \\
\hline \multirow[t]{2}{*}{ GDPpercapi e } & $-0.002^{* * *}$ & $-0.001^{* * *}$ & 0 & $-0.002^{* * *}$ & $-0.000^{* * *}$ & 0 \\
\hline & 0 & 0 & -0.001 & 0 & 0 & 0 \\
\hline \multirow[t]{2}{*}{ _cons } & 33.911 & 7.734 & 39.855 & 33.063 & -0.031 & $-7.509^{* *}$ \\
\hline & -33.957 & -10.472 & -44.604 & -33.851 & -0.117 & -3.6 \\
\hline $\mathbf{N}$ & 132 & 132 & 169 & 132 & 169 & 169 \\
\hline chi2 & 526.3 & 2271.5 & 150.9 & 500.7 & 6765.1 & 828.1 \\
\hline
\end{tabular}


Table 8 : Results - Islamic banks

\begin{tabular}{lcccccc}
\hline & & \multicolumn{5}{c}{ Islamic Banks } \\
\hline \multirow{3}{*}{ IA } & VAIC & HCVA & SCVA & ICVA & PCVA & ComAdv \\
& $6.485^{* * *}$ & $3.262^{* * *}$ & $2.203^{* * *}$ & $6.259^{* * *}$ & $0.178^{* * *}$ & $4.644^{* * *}$ \\
OIA & -0.007 & -0.231 & -0.343 & -0.029 & -0.019 & -1.168 \\
& $-139.521^{* *}$ & $-75.728^{* * *}$ & $-69.325^{* * *}$ & $-142.150^{* *}$ & $-4.607^{* * *}$ & $-776.533^{* * *}$ \\
IAI & -58.001 & -25.29 & -24.124 & -59.239 & -0.903 & -158.663 \\
& $-0.211^{* * *}$ & $-0.130^{* * *}$ & $-0.090^{* * *}$ & $-0.210^{* * *}$ & $-0.003^{* * *}$ & $-0.138^{*}$ \\
Size & -0.005 & -0.02 & -0.015 & -0.007 & 0 & -0.076 \\
& $0.176^{* * *}$ & 0.597 & 0.001 & $0.202^{* * *}$ & 0.012 & $-1.821^{* *}$ \\
Lev & -0.033 & -0.556 & -0.281 & 0 & -0.01 & -0.836 \\
& $0.563^{* * *}$ & $0.186^{* * *}$ & $0.246^{* * *}$ & $0.550^{* * *}$ & $0.006^{*}$ & $0.531^{* * *}$ \\
Concent & -0.024 & -0.044 & -0.014 & -0.029 & -0.003 & -0.107 \\
& $-0.022^{* * *}$ & $-0.010^{* * *}$ & $-0.010^{* * *}$ & $-0.022^{* * *}$ & 0 & $-0.024^{* * *}$ \\
GDPpercapi $\sim \mathbf{e}$ & -0.003 & -0.003 & -0.001 & -0.003 & 0 & -0.008 \\
& $-0.004^{* * *}$ & $-0.002^{* * *}$ & $-0.002^{* * *}$ & $-0.004^{* * *}$ & $-0.000^{* * *}$ & -0.002 \\
_cons & 0 & 0 & -0.001 & 0 & 0 & -0.001 \\
& $33.288^{* * *}$ & 12.383 & $13.972^{* * *}$ & $32.623^{* * *}$ & 0.085 & $45.403^{* * *}$ \\
N & -4.031 & -7.865 & -0.221 & -3.697 & -0.197 & -8.636 \\
Chi2 & 32 & 32 & 32 & 32 & 32 & 32 \\
\hline
\end{tabular}

Note: Coefficient is reported with standard error. Significance is denoted as follows: *** $\mathrm{p}<0.01,{ }^{* *} \mathrm{p}<0.05,{ }^{*} \mathrm{p}<0.10$. VAIC, SCVA, ICVA, PCVA, and competitive advantage are dependent variables. The intangible assets, other intangible assets, and intangible asset investment are independent variables. The control variables include size, leverage, and concentration. 
Competitive Advantage in Banking

Table 9 : Results - Conventional banks

\begin{tabular}{lcccccc}
\hline & \multicolumn{7}{c}{ Conventional Banks } \\
\hline \multirow{3}{*}{ IA } & VAIC & HCVA & SCVA & ICVA & PCVA & ComAdv \\
OIA & -82.958 & -1.947 & -22.844 & -83.474 & 0.124 & 5.89 \\
& -69.893 & -11.903 & -30.354 & -70.018 & -0.131 & -7.879 \\
IAI & 4.479 & $6.410^{* * *}$ & 0.764 & 4.153 & $0.145^{* * *}$ & $-5.804^{* * *}$ \\
& -3.224 & -0.801 & -2.165 & -3.5 & -0.019 & -0.27 \\
Size & 0 & 0 & 0 & 0 & $-0.000^{* * *}$ & $-0.000^{* * *}$ \\
& -0.001 & 0 & 0 & -0.001 & 0 & 0 \\
Lev & 0.798 & 1.185 & -2.144 & 0.858 & $0.033^{* * *}$ & 0.006 \\
& -2.072 & -0.968 & -3.009 & -2.114 & -0.009 & -0.222 \\
Concent & -0.235 & 0.019 & -0.001 & -0.236 & $-0.000^{* * *}$ & $-0.005^{* * *}$ \\
& -0.278 & -0.047 & -0.006 & -0.279 & 0 & -0.001 \\
GDPpercapi $\sim \mathbf{e}$ & -0.032 & $-0.013^{* * *}$ & -0.021 & -0.031 & $-0.000^{* *}$ & $0.007^{* * *}$ \\
& -0.02 & -0.004 & -0.022 & -0.02 & 0 & -0.002 \\
cons & $-0.003^{*}$ & $-0.001^{* * *}$ & 0 & $-0.003^{*}$ & $-0.000^{* * *}$ & 0 \\
& -0.001 & 0 & -0.001 & -0.002 & 0 & 0 \\
N & 39.691 & 3.45 & 49.18 & 38.486 & -0.121 & $-8.219^{* * * *}$ \\
chi2 & -46.628 & -12.92 & -56.621 & -47.173 & -0.133 & -2.69 \\
\hline
\end{tabular}

Note: The coefficient is reported with a standard error. The significance is denoted as follows: ${ }^{* * *} \mathrm{p}<0.01,{ }^{* *} \mathrm{p}<0.05,{ }^{*} \mathrm{p}<0.10$. The VAIC, SCVA, ICVA, PCVA, and competitive advantage are the dependent variables. The intangible assets, other intangible assets, and intangible asset investment are the independent variables. The control variables include size, leverage, and concentration. 
Table 10 : Robustness Analysis - Overall banks

\begin{tabular}{|c|c|c|c|c|c|c|c|c|}
\hline & \multicolumn{8}{|c|}{ Overall } \\
\hline & TQ & C & $\mathrm{A}$ & $\mathrm{M}$ & E1 & E2 & $\mathrm{L}$ & $\mathrm{S}$ \\
\hline \multirow[t]{2}{*}{ IA } & -0.008 & 0.548 & 0.035 & $1.500^{* * *}$ & $1.470^{* * *}$ & $32.112^{* * *}$ & 0.071 & 0 \\
\hline & -0.02 & -2.322 & -0.09 & -0.186 & -0.444 & -8.18 & -0.06 & -0.004 \\
\hline \multirow[t]{2}{*}{ OIA } & $0.047^{* * *}$ & 0.581 & $0.048^{* * *}$ & $-0.103^{* * *}$ & $-5.690^{* * *}$ & 7.916 & 0.052 & 0.002 \\
\hline & -0.015 & -2.567 & -0.009 & -0.029 & -1.167 & -19.515 & -0.106 & -0.002 \\
\hline \multirow[t]{2}{*}{ IAI } & 0 & 0 & $-0.000^{* * *}$ & 0 & $-0.000^{* *}$ & $-0.005^{*}$ & $0.000^{*}$ & $-0.000^{*}$ \\
\hline & 0 & 0 & 0 & 0 & 0 & -0.003 & 0 & 0 \\
\hline \multirow[t]{2}{*}{ Size } & 0.011 & -1.439 & -0.007 & -0.038 & -0.124 & 0.288 & 0.008 & $0.010^{* *}$ \\
\hline & -0.01 & -1.111 & -0.008 & -0.025 & -0.403 & -11.036 & -0.023 & -0.004 \\
\hline \multirow[t]{2}{*}{ Lev } & $-0.000^{* *}$ & $0.031^{* * *}$ & 0 & $-0.000^{* * *}$ & 0.001 & 0.159 & $0.001^{* * *}$ & 0 \\
\hline & 0 & -0.009 & 0 & 0 & -0.003 & -0.101 & 0 & 0 \\
\hline \multirow[t]{2}{*}{ Concent } & $0.001^{* * *}$ & -0.014 & 0 & 0 & $-0.016^{* * *}$ & -0.276 & $-0.000^{* *}$ & 0 \\
\hline & 0 & -0.01 & 0 & 0 & -0.005 & -0.17 & 0 & 0 \\
\hline \multirow[t]{2}{*}{ GDPpercapi $\sim$ e } & $0.000^{* * * *}$ & -0.001 & 0 & 0 & -0.001 & $-0.009^{*}$ & 0 & $-0.000^{* * *}$ \\
\hline & 0 & -0.001 & 0 & 0 & 0 & -0.005 & 0 & 0 \\
\hline \multirow[t]{2}{*}{ _cons } & $-0.660^{* * *}$ & $41.117^{* *}$ & 0.037 & 0.479 & $18.678^{* *}$ & 292.914 & $0.820^{* * *}$ & -0.083 \\
\hline & -0.238 & -16.753 & -0.119 & -0.366 & -7.935 & -266.596 & -0.284 & -0.054 \\
\hline $\mathbf{N}$ & 169 & 169 & 155 & 163 & 169 & 169 & 169 & 169 \\
\hline chi2 & 78.75 & 1988.6 & 1006.1 & 1679.7 & 625 & 3083.2 & 228 & 198.4 \\
\hline
\end{tabular}

Note: The coefficient is reported with a standard error. The significance is denoted as follows: ${ }^{* *} \mathrm{p}$ $<0.01,{ }^{* *} \mathrm{p}<0.05,{ }^{*} \mathrm{p}<0.10$. Tobin's $\mathrm{Q}$ and capital adequacy, asset management, management quality, earnings, liquidity, and sensitivity (CAMELS) are the dependent variables. The intangible assets, other intangible assets, and the intangible asset investment are the independent variables. The control variables include size, leverage, concentration, and the GDP per capita. 
Competitive Advantage in Banking

Table 11 : Robustness Analysis - Islamic banks

\begin{tabular}{lcccccccc}
\hline & & \multicolumn{7}{c}{ Islamic Banks } \\
\hline \multirow{4}{*}{ IA } & TQ & $\mathrm{C}$ & $\mathrm{A}$ & $\mathrm{M}$ & $\mathrm{E} 1$ & $\mathrm{E} 2$ & $\mathrm{~L}$ & $\mathrm{~S}$ \\
& -0.021 & 1.793 & -0.017 & $1.389^{* * *}$ & $5.550^{* * *}$ & $46.418^{* * *}$ & $-0.062^{* *}$ & $-0.016^{* * *}$ \\
OIA & -0.017 & -6.669 & -0.011 & -0.035 & -1.354 & -14.894 & -0.028 & -0.003 \\
& $-6.323^{*}$ & $2781.827^{* * *}$ & $13.071^{* * *}$ & -1.327 & $-737.530^{* * *}$ & $-1880.009^{* * *}$ & -4.013 & 0.145 \\
IAI & -3.531 & -1217.123 & -0.291 & -15.789 & -179.474 & -491.799 & -2.972 & -0.603 \\
& $0.002^{* *}$ & $0.242^{* *}$ & $0.003^{* *}$ & $0.027^{* * *}$ & $-0.305^{* * *}$ & $-2.642^{* * *}$ & $-0.003^{* * *}$ & 0 \\
Size & -0.001 & -0.098 & -0.002 & -0.005 & -0.073 & -0.482 & -0.001 & 0 \\
& $0.057^{* * *}$ & $7.012^{* * *}$ & $-0.070^{* * *}$ & -0.063 & -0.199 & $6.971^{* * *}$ & $0.078^{* * *}$ & $0.014^{* * *}$ \\
Lev & -0.002 & -2.476 & -0.009 & -0.041 & -0.451 & -1.599 & -0.01 & -0.001 \\
& $-0.006^{* *}$ & -0.359 & $0.010^{* * *}$ & 0.003 & $0.475^{* * *}$ & $2.388^{*}$ & $-0.014^{* * *}$ & $-0.002^{* * *}$ \\
Concent & -0.003 & -0.787 & -0.002 & -0.004 & -0.128 & -1.361 & -0.005 & 0 \\
\multirow{2}{*}{ GDPpercapi $\sim$} & $0.001^{* * *}$ & $0.011^{*}$ & 0 & 0 & $-0.037^{* * *}$ & $-0.186^{* * *}$ & $0.000^{* *}$ & 0 \\
e & 0 & -0.006 & 0 & 0 & -0.01 & -0.065 & 0 & 0 \\
& 0 & $-0.013^{* * *}$ & 0 & 0 & $-0.004^{* *}$ & $-0.027^{* * *}$ & 0 & $-0.000^{* * *}$ \\
\multirow{4}{*}{ cons } & 0 & -0.004 & 0 & 0 & -0.001 & -0.01 & 0 & 0 \\
& $-1.263^{* * *}$ & -27.809 & $0.721^{* * *}$ & 0.974 & $46.410^{* * *}$ & $187.740^{*}$ & 0.005 & $-0.133^{* * *}$ \\
N & -0.152 & -34.931 & -0.115 & -0.735 & -10.239 & -101.298 & -0.078 & -0.011 \\
chi2 & 32 & 32 & 32 & 32 & 32 & 32 & 32 & 32 \\
\hline
\end{tabular}

Note: The coefficient is reported with a standard error. The significance is denoted as follows: ${ }^{* * *} \mathrm{p}$ $<0.01,{ }^{* *} \mathrm{p}<0.05,{ }^{*} \mathrm{p}<0.10$. Tobin's $\mathrm{Q}$ and capital adequacy, asset management, management quality, earnings, liquidity, and sensitivity (CAMELS) are the dependent variables. The intangible assets, other intangible assets, and intangible asset investment are the independent variables. The control variables include size, leverage, concentration, and the GDP per capita. 
Table 12 : Robustness Analysis - Conventional banks

\begin{tabular}{|c|c|c|c|c|c|c|c|c|}
\hline & \multicolumn{8}{|c|}{ Conventional Banks } \\
\hline & TQ & C & A & $\mathrm{M}$ & E1 & E2 & $\mathrm{L}$ & $\mathrm{S}$ \\
\hline \multirow[t]{2}{*}{ IA } & -0.085 & $87.574^{* * *}$ & 0.242 & 0.202 & 9.761 & $318.114^{* *}$ & 0.365 & 0.022 \\
\hline & -0.154 & -17.846 & -0.175 & -0.294 & -7.14 & -138.521 & -1.162 & -0.022 \\
\hline \multirow[t]{2}{*}{ OIA } & $0.033^{* * *}$ & -0.052 & $0.046^{* * *}$ & $-0.125^{* * *}$ & $-7.392^{* * *}$ & 9.606 & 0.036 & 0.001 \\
\hline & -0.011 & -1.414 & -0.014 & -0.025 & -0.644 & -13.608 & -0.096 & -0.003 \\
\hline \multirow[t]{2}{*}{ IAI } & 0 & 0 & $-0.000^{* * *}$ & 0 & $-0.000^{* *}$ & $-0.005^{* *}$ & $0.000^{* * *}$ & $-0.000^{*}$ \\
\hline & 0 & 0 & 0 & 0 & 0 & -0.002 & 0 & 0 \\
\hline \multirow[t]{2}{*}{ Size } & -0.003 & $-1.767^{* *}$ & -0.007 & $-0.050^{* * *}$ & -0.395 & 6.709 & 0.006 & $0.010^{*}$ \\
\hline & -0.014 & -0.806 & -0.008 & -0.019 & -0.485 & -12.607 & -0.035 & -0.005 \\
\hline \multirow[t]{2}{*}{ Lev } & $-0.000^{*}$ & $0.025^{* * *}$ & 0 & $-0.000^{* *}$ & 0 & 0.124 & $0.001^{* * *}$ & 0 \\
\hline & 0 & -0.004 & 0 & 0 & -0.004 & -0.102 & 0 & 0 \\
\hline \multirow[t]{2}{*}{ Concent } & $0.000^{* *}$ & -0.006 & 0 & 0 & $-0.012^{* *}$ & -0.288 & $-0.000^{* *}$ & 0 \\
\hline & 0 & -0.008 & 0 & 0 & -0.005 & -0.197 & 0 & 0 \\
\hline \multirow[t]{2}{*}{ GDPpercapi e } & $0.000^{* * *}$ & 0.001 & 0 & 0 & 0 & $-0.012^{* *}$ & 0 & $-0.000^{* * *}$ \\
\hline & 0 & -0.001 & 0 & 0 & 0 & -0.006 & 0 & 0 \\
\hline \multirow[t]{2}{*}{ _cons } & -0.49 & $28.747^{* *}$ & 0.046 & $0.542^{* * *}$ & 16.279 & 228.603 & $0.923^{* *}$ & -0.084 \\
\hline & -0.317 & -13.05 & -0.126 & -0.159 & -10.175 & -313.364 & -0.46 & -0.065 \\
\hline $\mathbf{N}$ & 137 & 137 & 134 & 137 & 137 & 137 & 137 & 137 \\
\hline chi2 & 641.6 & 2083.3 & 388.4 & 391.5 & 6585.5 & 4687.6 & 421.9 & 563.4 \\
\hline
\end{tabular}

Note: The coefficient is reported with a standard error. The significance is denoted as follows: ${ }^{* * *} \mathrm{p}$ $<0.01,{ }^{* *} \mathrm{p}<0.05,{ }^{*} \mathrm{p}<0.10$. Tobin's $\mathrm{Q}$ and capital adequacy, asset management, management quality, earnings, liquidity, and sensitivity(CAMELS) are the dependent variables. The intangible assets, other intangible assets, and intangible asset investment are the independent variables. The control variables include size, leverage, concentration, and the GDP per capita. 